\title{
Monitoring Disease Activity and Progression in Crohn's Disease. A Swiss Perspective on the IBD Ahead 'Optimised Monitoring' Recommendations
}

\author{
Bernhard Sauter $^{a} \quad$ Christoph Beglinger ${ }^{d}$ Marc Girardin $^{e} \quad$ Andrew Macpherson $^{f}$ \\ Pierre Michetti $^{\text {h }}$ Alain Schoepfer ${ }^{i}$ Frank Seiboldg Stephan R. Vavricka ${ }^{b}$ \\ Gerhard Rogler ${ }^{c}$ IBD Ahead Swiss National Steering Committee \\ a GastroZentrum Hirslanden, Zurich, ${ }^{b}$ Division of Gastroenterology and Hepatology, Triemli Hospital, ' Division of \\ Gastroenterology and Hepatology, University Hospital, Zurich, ${ }^{\mathrm{d}}$ Department of Gastroenterology and Hepatology, \\ University Hospital, Basel, 'Division of Gastroenterology and Hepatology, Geneva University Hospitals, Geneva, \\ fDivision of Gastroenterology, Department of Medicine, University Hospital Bern, ${ }^{9}$ Department of Gastroenterology, \\ Tiefenau Hospital, Bern, ${ }^{\mathrm{h} C l i n i q u e ~ L a ~ S o u r c e-B a u l i e u, ~ L a u s a n n e, ~ a n d ~ ' D e p a r t m e n t ~ o f ~ G a s t r o e n t e r o l o g y ~ a n d ~}$ \\ Hepatology, University Hospital Centre, Lausanne, Switzerland
}

\section{Key Words \\ Chronic inflammatory bowel disease - Crohn's disease . \\ Disease monitoring $\cdot$ Recommendations - Best-practice guidelines - Endoscopy · Multidetector computed tomography - Calprotectin - Small intestine contrast ultrasonography · Contrast-enhanced ultrasound}

\footnotetext{
Abstract

Background and Aims: The structured IBD Ahead 'Optimised Monitoring' programme was designed to obtain the opinion, insight and advice of gastroenterologists on optimising the monitoring of Crohn's disease activity in four settings: (1) assessment at diagnosis, (2) monitoring in symptomatic patients, (3) monitoring in asymptomatic patients, and (4) the postoperative follow-up. For each of these settings, four monitoring methods were discussed: (a) symptom assessment, (b) endoscopy, (c) laboratory markers, and (d) imaging. Based on literature search and expert opinion compiled during an international consensus meeting, recommendations were given to answer the question 'which diagnostic method, when, and how often'. The International IBD Ahead Expert Panel advised to tailor this guidance to the healthcare system and the
}

special prerequisites of each country. The IBD Ahead Swiss National Steering Committee proposes best-practice recommendations adapted for Switzerland. Methods: The IBD Ahead Steering Committee identified key questions and provided the Swiss Expert Panel with a structured literature research. The expert panel agreed on a set of statements. During an international expert meeting the consolidated outcome of the national meetings was merged into final statements agreed by the participating International and $\mathrm{Na}$ tional Steering Committee members - the IBD Ahead 'Optimized Monitoring' Consensus. Results: A systematic assessment of symptoms, endoscopy findings, and laboratory markers with special emphasis on faecal calprotectin is deemed necessary even in symptom-free patients. The choice of recommended imaging methods is adapted to the specific situation in Switzerland and highlights the importance of ultrasonography and magnetic resonance imaging besides endoscopy. Conclusion: The recommendations stress the importance of monitoring disease activity on a regular basis and by objective parameters, such as faecal calprotectin and endoscopy with detailed documentation of findings. Physicians should not rely on symptoms only and adapt the monitoring schedule and choice of options to individual situations.

\section{KARGER}

E-Mail karger@karger.com www.karger.com/dig
(C) 2014 S. Karger AG Basel

$0012-2823 / 14 / 0894-0299 \$ 39.50 / 0$ 


\section{Introduction}

Crohn's disease (CD) is a chronic inflammatory disease of the gastrointestinal tract that may lead to irreversible bowel damage such as strictures or fistulae. Despite absence of clinical symptoms, subclinical inflammation often persists and reflects the progression of the disease. Disease progression, frequently resulting in structural gut wall damage, often requires surgical interventions and is frequently associated with some loss of organ function. Therefore, a shift of the therapeutic target has been evolving from symptomatic remission towards mucosal healing to prevent structural gut wall damage. The absence of symptoms and lack of inflammatory markers in association with mucosal healing has also been termed as 'deep remission' which has been suggested as a new treatment target $[1,2]$. Along the trajectory towards this target, however, a relevant number of questions remain open. As mucosal healing cannot be expected to occur in all or the vast majority of symptom-free patients, the way of disease monitoring depends on the treatment target. Based on the new treatment targets and subsequent new monitoring challenges, the IBD Ahead programme 2011 identified the most relevant unanswered questions relating to the monitoring of disease activity and progression in CD [3].

By means of a structured consensus-finding process, key clinical data and experience were collected to define the best practice of monitoring in regard to symptom assessment, biological markers, endoscopy, and imaging. These data were consolidated to provide case-based evidence to complement the current ECCO guidelines for the management of $\mathrm{CD}$. Following the international consensus, the programme encourages adaptation according to the situation in the different countries. For Switzerland, several aspects are specific which are not typical for a number of countries involved in the consensus process. First, faecal calprotectin is already a well-established marker to assess the presence or absence (i.e. mucosal healing) of mucosal inflammation, which is readily used in Switzerland but, mainly due to logistical or reimbursement reasons, much less so in many other countries. Second, magnetic resonance imaging (MRI) is accessible for most Swiss patients, whereas in other countries such as the United States or United Kingdom, computed tomography $(\mathrm{CT})$ is easier accessible than MRI. Furthermore, ultrasonography (US), an excellent monitoring tool, is performed by gastroenterologists in Switzerland, which is not the case in many European countries or in the United States.
If applicable, for each item evidence or a recommendation was sought to answer the questions - Which patient? When? How often?

The literature was reviewed to generate evidencebased recommendations. These were discussed and assessed at national meetings in the 36 participating countries. When published evidence was lacking, experts attending the national meetings compiled best-practice recommendations.

At the International IBD Ahead Meeting in September 2011, in Dusseldorf, the consolidated outcome of the literature reviews plus national meetings' outputs were merged into final statements which were agreed upon by the participating International and National Steering Committee members.

\section{Methods}

Based on an initial data collection, the International Steering Committee Meeting selected important unanswered questions and areas of uncertainty in the management of $\mathrm{CD}$. The areas of main interest concerning the monitoring of $\mathrm{CD}$ activity were condensed into a framework (table 1) comprising four clinical settings, namely patients at baseline, symptomatic patients, asymptomatic patients, and postoperative patients, and four monitoring methods, symptom assessment, endoscopy, laboratory markers, and imaging.

To ensure tracking disease activity reliably during the course of the disease, a thorough assessment with detailed documentation at diagnosis is important.

\section{Assessment at Diagnosis}

\section{Symptom Assessment}

Symptom assessment should be used in each patient during each consultation. In clinical practice, gastroenterologists assess symptoms relying on their global clinical judgement. This simple and readily available method seems adequately reproducible. The International Consensus recommends using symptom assessment tools in all patients and during each consultation to establish a baseline value for future comparison (level D). The Crohn's Disease Activity Index (CDAI) [4], the HarveyBradshaw Index (HBI) [5], and the Inflammatory Bowel Disease Questionnaire (IBDQ) [6-9] are validated tools for evaluating symptoms before patients enter clinical trials (level A). A benefit of using the CDAI or HBI is their 
Table 1. International IBD Ahead Meeting: the underlying framework for monitoring recommendations in CD

$\begin{array}{llll}\begin{array}{l}\text { Symptom } \\ \text { assessment }\end{array} & \text { Endoscopy } & \begin{array}{l}\text { Laboratory } \\ \text { markers }\end{array} & \text { Imaging }\end{array}$

Assessment at diagnosis

Monitoring in symptomatic patients

Monitoring in asymptomatic patients

Monitoring in post-operative patients

For each patient scenario and monitoring method, literature findings and summary statements with evidence levels A-D (University of Oxford (UK) Centre for Evidence-Based Medicine, http://www.cebm.net/index.aspx?o=1025) are provided.

usefulness for therapeutic decisions at a later time point. They provide semi-objective information facilitating interpretation by colleagues in the same or different institutions. But CDAI and HBI might be too complex to be performed in daily practice, and there is little evidence from literature that using these scores improves outcomes.

\section{Endoscopy}

Endoscopy should be performed in all patients at baseline to establish location, extent, and severity of disease (level D). Independently of stage, lesions should be measured and documented carefully. Precise standardized description of endoscopic lesions including type, location, depth, and extent is advocated (level D). This may be achieved by endoscopic scoring tools such as the Crohn's Disease Endoscopy Index of Severity (CDEIS) or the Simple Endoscopic Score for Crohn's Disease (SES-CD).

Ileocolonoscopy, with visualisation of the terminal ileum and all colonic segments, should be performed (level A) $[1,10,11]$; at least two biopsies of every segment and the rectum (in areas that appear both normal and abnormal), should be taken to support diagnosis (level D) [12].

For the detection of upper gastrointestinal involvement, gastroscopy is recommended. Double balloon endoscopy or enteroscopy should be performed in suspected cases of small intestinal involvement (level A) [13-16].

Upper gastrointestinal endoscopy and biopsies are useful, particularly in paediatric patients and in adult patients with upper gastrointestinal symptoms (level D) [17-22].

Small-bowel capsule endoscopy (SBCE) or enteroscopy are recommended to support diagnosis in patients with a high clinical suspicion of CD with inconclusive ileocolonoscopy, gastroscopy and imaging evaluations (level B) [23-35]. Strictures should be excluded previously (level B).

\section{Laboratory Markers - Faecal Markers}

Routine laboratory and inflammatory marker assessments as well as faecal calprotectin measurement should be conducted in all patients to establish a baseline value for future comparison [36-46] (level D).

The recommended panel of markers are complete blood count, liver profile, albumin, iron studies, renal function, vitamin $B_{12}$, folic acid, and vitamin $D$ (level D).

C-reactive protein (CRP) should be measured to assess the initial inflammatory response (level D) [47-51]; of note, patients with CD may have normal CRP levels despite clinical activity and mucosal inflammation (level A) [52].

Faecal calprotectin should be assessed as a marker of intestinal inflammation (level B); stool analysis and culture, and Clostridium difficile toxin testing is also recommended (level D) [43, 44, 53].

\section{Imaging}

The international consensus recommends performing baseline imaging in all patients to assess the extent and severity of small bowel involvement and to rule out complications such as fibrostenosing or penetrating disease (level D).

In a patient with complaints suggestive of IBD, US should be the first-choice imaging modality [54-59] (level B). For an acutely ill patient who is admitted to the emergency unit with suspected CD, abdominal multidetector CT (MDCT) scanning is the recommended modality of choice (level B) [60-62].

To evaluate involvement of the small bowel, magnetic resonance enteroclysis or enterography are advised for staging (level A) [63-68]. The same diagnostic accuracy is provided by CT. CD patients usually undergo multiple abdominal imaging during a lifetime. The burden of ionizing radiation using CT scans is significant and should be minimized (level A) $[69,70]$. Therefore, in Switzerland 
(and also in other Western European countries, depending on availability) MRI is preferred over CT scan for the initial staging [71]. In the United States it was estimated that up to $0.5-2.0 \%$ of cancers could be attributed to the radiation of CT scans. The risks in other countries were found to be comparable (Germany 1.5\%, United Kingdom $0.6 \%)$ [72-74]. The exact cancer risk of recurrent lowdose radiation is difficult to calculate but it is definitely real. IBD patients are exposed to a significant level of diagnostic ionizing radiation over time. The median radiation exposure in patients with CD was found in a retrospective study to accumulate to $26.6 \mathrm{mSv}$ (range 0-279) during a period of 9 years [75].

For detection of stenosing small bowel lesions in patients presenting with symptoms suggestive of stricturing $\mathrm{CD}, \mathrm{MRI}$ is superior to barium studies (level B) [76]. In bowel distension, CT enteroclysis is superior to CT enterography (although less tolerated by patients), but diagnostic accuracy of both is comparable for the detection of stenotic lesions (level B) [77-80].

In cases of incomplete colonoscopy due to an impassable colonic stricture, colonic inflammatory lesions of the segment not explored by endoscopy can be evaluated by CT colonography (level B). MDCT techniques are highly accurate for the detection of extraintestinal manifestations, especially for abscesses and fistulae (level A) [68, 81]. MRI is the gold standard to image perianal lesions of patients with suspicion of CD (level A) [82-85]. Anorectal US is helpful to evaluate perianal abscesses (level B). Transdermal perineal US might be helpful to evaluate the exact anatomy of perianal complications (level C) [8692]. In general, MRI is preferred to a CT scan in order to avoid radiation.

Contrast-enhanced ultrasound (CEUS) and small intestine contrast ultrasound (SICUS) play a limited role in baseline assessment due to lack of standardisation and poor accessibility [93-96].

\section{Monitoring in Symptomatic Patients}

Routine monitoring of patients through symptom assessment, endoscopic evaluation, laboratory markers and imaging is important to ensure adequate response to therapeutic interventions and to optimise therapy (level D).

\section{Symptom Assessment}

In each consultation, symptom assessment should be performed. Persisting symptoms must be evaluated clinically, and appropriate guidance is desirable.
In regard to the choice of tools, the same recommendations apply as in baseline assessment. In everyday clinical practice, CDAI or HBI are sometimes used for therapeutic decisions in patients under immunosuppressive or biologic therapy.

Recommended re-evaluation intervals to evaluate the effect of therapeutic options depend on the chosen modality. Symptom evaluation is done (i) 2-4 weeks after initiating corticosteroids, (ii) 3-6 months after initiating immunosuppressive therapy (with earlier evaluation of side effects), and (iii) 8-12 weeks after initiating biologic therapy.

\section{Endoscopy}

In patients with unclear clinical presentation, endoscopy and especially colonoscopy should be performed if the result has an impact on treatment decisions, for instance introducing biological therapy (level D). In this case, endoscopic confirmation of disease activity is appropriate unless there is other objective evidence of active disease (level D). Before endoscopy, calprotectin may be used as a surrogate marker for inflammatory activity (level B) $[42-44,97]$.

The frequency of endoscopy is directed by clinical symptoms (level D). The type of endoscopic assessment should be determined by known sites of involvement and clinical presentation (level D). Capsule endoscopy or enteroscopy may be considered in patients with negative ileocolonoscopy and imaging evaluations (level D) [24, 98-101].

\section{Laboratory Markers}

Laboratory investigations should be conducted in all symptomatic patients (as well as prior to starting therapy) to assess disease activity and exclude intercurrent infection (level D). Blood markers should be used in clinical worsening and in suspicion of disease flare (level B) [102].

CRP is a helpful marker to monitor systemic inflammation in symptomatic patients (level A/Swiss consensus: level B) [102]. Concomitant complete blood count is recommended (level B) [103]. Faecal calprotectin can be used as a surrogate marker for inflammatory activity (level A) $[42-44,97]$ and to discriminate from functional symptoms (level C). Faecal cultures should be taken to exclude bacterial infections (level D). C. difficile infection should be ruled out $[104,105]$. Faecal cultures for parasites should be taken three times. Especially in patients under immunosuppressive therapy, biopsies should be taken to search for cytomegalovirus [106, 107].

The frequency of re-assessments will be determined by disease severity, treatment type, and therapeutic response (level D). 


\section{Imaging}

Small Bowel Symptoms

For small bowel symptoms, MRI enterography is the preferred mode to assess the extent and severity (level A) [63-68]. MRI can detect disease activity at a stricture and differentiate between inflammatory or fibrostenotic stricture, but the diagnostic power to discriminate the two has not been adequately evaluated (level B). MRI is also suitable for monitoring disease activity and evaluating $\mathrm{CD}$ preoperatively (level B) [108-110]. Small bowel US might also be useful (level B) [111]. Due to the radiation risks associated with $\mathrm{CT}$ enterography and barium techniques (level A), their routine use is not recommended (level D) [112-114].

\section{Complications}

CT scans are useful in patients with fulminant symptoms to detect bowel obstruction, perforation, or toxic colon distension (level B) [60-62]. Abdominal MDCT is the modality of choice for an acutely ill CD patient presenting in the emergency room. The MDCT findings correlate well with disease activity (level B) [60-62]. Contrast-enhanced CT of the abdomen/pelvis or US are useful in acutely ill patients to rule out complications such as intra-abdominal abscesses (level B) $[61,68,115$, 116].

In suspected acute complications such as strictures, perforations, abscesses, and obstructions, plain abdominal US (level B) and/or CT scans should be used (level D) $[57,117,118]$. MRI is accurate in imaging extraluminal alterations, too (level A).

Pelvic MRI (level A) and/or transperineal (level C) and rectal US (level B) should be used to assess perianal disease and to rule out perianal abscess. Transdermal perianal US might enhance the diagnostic accuracy regarding perianal fistulae and abscesses (level C) [82-92]. Imaging should be performed in combination with examination under anaesthesia (level D).

Due to radiation risks associated with CT enterography, its use should be limited (level D).

The frequency of conventional radiology and CT are directed by the clinical situation (level D). Acute complications, like abscesses, ileus, or perforation, should be diagnosed immediately (level C).

CEUS and specific components (Doppler flow and bowel wall thickness) of US were observed to be appropriate to monitor the efficacy of the therapy; however, the frequency of the follow-up is not defined (level D). CEUS is not frequently used in clinical practice [9396].

Monitoring Disease Activity and

Progression in Crohn's Disease

\section{Monitoring in Asymptomatic Patients}

As outlined in the Introduction, there is a discrepancy between symptoms and inflammatory disease activity. The rising importance of new treatment targets such as mucosal healing and deep remission require strategies to monitor disease beyond symptoms which may include laboratory markers, endoscopy, and imaging (level D).

\section{Symptom Assessment}

The CDAI or HBI, as well as the IBDQ have been used for verifying remission in $\mathrm{CD}$ patients (level A). It is not common clinical practice to measure these indices in asymptomatic patients. Evidence exists that there is a continued impact on quality of life by the disease, even when inactive. Therefore, determination of IBDQ in patients in remission might be of value (level B) [6-9]. Symptom assessment tools should be used during each consultation (level D), the frequency of which depends on the patient's treatment regimen, typically every 3-6 months (level D).

In general, physicians should wait 3-6 months before judging efficacy of immunosuppressive therapy and 8-12 weeks before judging biologic efficacy (level D). Side effects need to be evaluated earlier.

\section{Endoscopy}

Ileocolonoscopy is recommended in ileocolonic disease; in patients with upper gastrointestinal involvement, upper gastrointestinal endoscopy is recommended (level D). Endoscopy in asymptomatic patients may be appropriate when there is concern about disease progression and when therapeutic modifications are considered (level D). Endoscopic healing is associated with a lower rate of hospitalisation, surgery, steroid- and biological-free remission (level B) [119-124]. There is insufficient evidence to recommend routine endoscopy to assess mucosal healing in all patients, but it is likely to be appropriate within 6 months of starting biological therapy (level $\mathrm{D}$ ) and is best performed before stopping biological therapy (level C) [125]. Endoscopies without clinical consequence ('routine assessments') should be avoided (level D).

\section{Laboratory Investigations}

Laboratory investigations should be part of the global assessment in an asymptomatic patient (level D) at each visit (level D). As a marker of inflammation, CRP and total blood count can be useful to assess inflammation despite absence of clinical symptoms (level B). Calprotectin 
can be used as surrogate marker for inflammatory activity (level A).

Routine monitoring of inflammatory markers should be performed on an individual basis and depending on the type of medication (e.g. TNF- $\alpha$; level C) every 3-12 months (level D).

Vitamin $D$ and $B_{12}$ assessments may help to detect disease complications (level B).

\section{Imaging}

Imaging in the asymptomatic patient may be appropriate when there is concern about disease progression and when therapeutic modifications are considered (level D). To assess these patients, MRI (enterography, enteroclysis) or abdominal US is preferred (level D). In asymptomatic patients, there is no indication to use conventional radiology or CT (level D). Some clinicians control their symptomless patients with US (level D). US may be helpful to detect inflammation before clinical symptoms occur. The frequency of US examinations should be dependent on the individual risk profile of the patient.

\section{Monitoring in Postoperative Patients}

It is acknowledged that disease may recur in the absence of symptoms, and therefore symptoms alone are inadequate when monitoring for postoperative recurrence (level A) [126-128]. A combination of symptom assessment plus endoscopic evidence of recurrence is the present standard of care for assessing outcomes in postoperative CD.

\section{Symptom Assessment}

Symptoms should be assessed within 3 months after surgery (level D), followed by regular visits for instance every 3 months in the first year after surgery, then every 6-12 months depending on the risk (level D) as assessed preoperatively.

\section{Endoscopy}

Ileocolonoscopy is the gold standard to confirm the diagnosis of postoperative recurrence by defining the presence and severity of morphologic recurrence (level B) and predicting the clinical course (level B) $[126,129-$ 133]. The frequency of further endoscopies depends on the findings of the first endoscopy after surgery, and on the future disease course (level D).

It is recommended to perform ileocolonoscopy between 3 and 6 months postoperatively to check for re- lapses after surgery (level D) $[126,132,133]$. There is no evidence that performing ileocolonoscopy more than once improves outcomes (level B). Capsule endoscopy is a potential alternative in selected patients (level D). Rutgeerts score should be used to assess recurrence in the neo-terminal ileum (level D).

\section{Laboratory Investigations}

Routine laboratory investigations should be conducted (level D), as well as CRP assessments (level C). Calprotectin can indicate disease recurrence after surgery (level C) [134-136]. Determination of vitamin $B_{12}$ is mandatory after ileocolonic resection (level D) 6 months postoperatively.

Postoperative measurement of faecal markers 6 months after surgery and after first endoscopy is regarded as a suitable non-invasive postsurgery monitoring tool (level D).

There is a disconnection between symptoms and endoscopic disease activity, therefore routine monitoring of inflammatory markers every 3-6 months is recommended (level D). The need for vitamin $B_{12}$ substitution should be checked regularly (level D).

\section{Imaging}

US plays a role in detecting postoperative recurrence in CD. US should be performed 3 months after small bowel resection. In patients at high risk of recurrence, US can be performed regularly even when the index endoscopy 6 months after surgery is normal. SICUS can be a choice to follow-up patients with small bowel resection.

Due to the radiation risks associated with CT enterography, its routine use is not recommended (level D) whereas MRI enterography is a legitimate choice.

\section{Conclusion}

Due to good availability of MRI in Switzerland, one of the main characteristics of the country-specific recommendations concerns the reduced use of CT to minimize the radiation burden during the course of the disease. Currently, positron emission tomography does not play a role in the diagnostic management of CD in Switzerland. After establishing a baseline status, endoscopy (in asymptomatic patients) should only be performed if the results trigger a therapeutic consequence. To assess inflammation even in asymptomatic patients, calprotectin can be used as a surrogate marker for inflammatory ac- 
tivity in the gastrointestinal tract. Symptom assessment and laboratory evaluation on a regular basis, depending also on the type of therapy, should ensure that the inflammation is continuously inhibited to achieve a sustained remission.

Follow-up of asymptomatic patients by US is an option which is available in Switzerland and that should be used more frequently. Calprotectin is well accepted in Switzerland and should be part of the standard of care in $\mathrm{CD}$ as outlined in these recommendations.

In general, Swiss resources for the monitoring of $\mathrm{CD}$ patients are excellent. An appropriate use will guarantee optimal care for our patients and will bring us closer to the treatment goal of preventing irreversible bowel wall damage.

\section{Disclosure Statement}

Funding: Abbott provided funding for the IBD Ahead programme and for the development of the manuscript. Ulrike S. Novotny (novoMEDtext ag) provided medical writing and editorial support to the authors in the development of the manuscript; financial support for these services was provided by Abbott. The authors maintained complete control over the direction and the content of the paper. Abbott did not review or approve the manuscript content, and had no influence over the manuscript content or the decision to submit for publication.

B.S. has consulted for Abbott/AbbVie Switzerland, Essex/ MSD Switzerland, and UCB, and has received speaker's hono- raria from Abbott, MSD, UCB, and Vifor. C.B. has consulted for Abbott Switzerland, Essex Chemie, MSD Switzerland, Takeda International, UCB, and Vifor Switzerland; has received speaker's honoraria from Abbott, FALK, MSD, UCB, and Vifor, and has received educational grants and research grants from Abbott Switzerland, Essex Chemie, MSD and UCB and Vifor. M.G. has consulted for AbbVie and MSD, and has received speaker's honoraria from AbbVie, UCB and MSD. A.M. has no conflicts of interest to disclose. P.M. has consulted for Abbott Switzerland, AbbVie International, Berlex, Centocor, Delenex, MSD Switzerland and International, UCB, and Vifor Switzerland; has received speaker's honoraria from Abbott, AbbVie, FALK, MSD, UCB, and Vifor, and has received educational grants and research grants from Essex Chemie, MSD, and UCB. A.S. has consulted for AbbVie and MSD, Switzerland; has received speaker's honoraria from AbbVie Switzerland, and MSD Switzerland, and has received research grants from Tillotts Switzerland and MSD Switzerland. F.S. has consulted for Abbott/AbbVie Switzerland, Essex/MSD Switzerland, and UCB; has received speaker's honoraria from Abbott, MSD, UCB, and Vifor, and has received a non-restricted research grant from MSD. S.V. has consulted for Abbott/AbbVie Switzerland, Essex/MSD Switzerland, UCB, Tillotts, Vifor International and Vifor Switzerland; has received speaker's honoraria from Abbott, FALK, MSD, Tillotts, UCB, and Vifor, and has received educational grants and research grants from Abbott, Essex/ MSD, UCB. G.R. has consulted for Abbott/AbbVie Switzerland, Abbott International, FALK Germany, Essex/MSD Switzerland, Novartis, Roche, UCB, Tillotts, Vifor International and Vifor Switzerland; has received speaker's honoraria from Abbott, FALK, MSD, Phadia, Tillotts, UCB, and Vifor, and has received educational grants and research grants from Abbot, Ardeypharm, Essex/MSD, FALK, Flamentera, Novartis, Roche, Tillotts, UCB and Zeller.

\section{References}

1 Dignass A, Van Assche G, Lindsay JO, Lémann M, Söderholm J, Colombel JF, Danese S, D’Hoore A, Gassull M, Gomollón F, Hommes DW, Michetti P, O'Morain C, Öresland T, Windsor A, Stange EF, Travis SPL: The second European evidence-based Consensus on the diagnosis and management of Crohn's disease: Current management. J Crohns Colitis 2010;4:28-62.

2 Van Assche G, Dignass A, Panes J, Beaugerie L, Karagiannis J, Allez M, Ochsenkühn T, Orchard T, Rogler G, Louis E, Kupcinskas L, Mantzaris G, Travis S, Stange E: The second European evidence-based Consensus on the diagnosis and management of Crohn's disease: definitions and diagnosis. J Crohns Colitis $2010 ; 4: 7-27$.

-3 Ferrante M, Karmiris K, Newnham E, Siffledeen J, Zelinkova Z, van Assche G, Lakatos PL, Panés J, Sturm A, Travis S, van der Woude CJ, Reinisch W, Colombel JF, Panaccione R: Physician perspectives on unresolved issues in the use of conventional therapy in Crohn's disease: results from an international survey and discussion programme. J Crohns Colitis 2012;6:116-131.
-4 Best WR, Becktel JM, Singleton JW: Rederived values of the eight coefficients of the Crohn's Disease Activity Index (CDAI). Gastroenterology 1979;77:843-846.

$\checkmark 5$ Best WR: Predicting the Crohn's Disease Activity Index from the Harvey-Bradshaw Index. Inflamm Bowel Dis 2006;12:304-310.

6 Irvine EJ: Quality of life - measurement in inflammatory bowel disease. Scand J Gastroenterol Suppl 1993;199:36-39.

-7 Irvine EJ, Feagan B, Rochon J, Archambault A, Fedorak RN, Groll A, Kinnear D, Saibil F, McDonald JW: Quality of life: a valid and reliable measure of therapeutic efficacy in the treatment of inflammatory bowel disease. Canadian Crohn's Relapse Prevention Trial Study Group. Gastroenterology 1994;106:287-296.

8 Irvine EJ: Quality of Life in inflammatory bowel disease: biases and other factors affecting scores. Scand J Gastroenterol Suppl 1995; 208:136-140.

-9 Irvine EJ, Zhou Q, Thompson AK: The Short Inflammatory Bowel Disease Questionnaire: a quality of life instrument for community physicians managing inflammatory bowel disease. CCRPT Investigators. Canadian Crohn's Relapse Prevention Trial. Am J Gastroenterol 1996;91:1571-1578.

10 Pera A, Bellando P, Caldera D, Ponti V, Astegiano M, Barletti C, David E, Arrigoni A, Rocca G, Verme G: Colonoscopy in inflammatory bowel disease. Diagnostic accuracy and proposal of an endoscopic score. Gastroenterology 1987;92:181-185.

11 Moum B, Ekbom A, Vatn MH, Aadland E, Sauar J, Lygren I, Schulz T, Stray N, Fausa O: Inflammatory bowel disease: re-evaluation of the diagnosis in a prospective populationbased study in south eastern Norway. Gut 1997;40:328-332.

12 Surawicz CM, Belic L: Rectal biopsy helps to distinguish acute self-limited colitis from idiopathic inflammatory bowel disease. Gastroenterology 1984;86:104-113.

13 Chang DK, Kim JJ, Choi H, Eun CS, Han DS, Byeon JS, Kim JO:Double balloon endoscopyin small intestinal Crohn's disease and other inflammatory diseases such as cryptogenic multifocal ulcerous stenosing enteritis (CMUSE). GastrointestEndosc2007;66(3 suppl):S96-S98. 
14 Kondo J, Iijima H, Abe T, Komori M, Hiyama S, Ito T, Nakama A, Tominaga K, Kubo M, Suzuki K, Iwanaga Y, Ebara R, Takeda A, Tsuji S, Nishida T, Tsutsui S, Tsujii M, Hayashi N: Roles of double-balloon endoscopy in the diagnosis and treatment of Crohn's disease: a multicenter experience. J Gastroenterol 2010;45: 713-720.

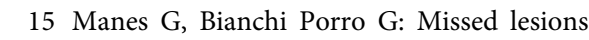
with conventional endoscopy discovered by double-balloon enteroscopy: endoscopist or instrument? Aliment Pharmacol Ther 2009; 29:918-919; author reply 919-920.

- 16 Sunada K, Yamamoto H, Yano T, Sugano K: Advances in the diagnosis and treatment of small bowel lesions with Crohn's disease using double-balloon endoscopy. Therap Adv Gastroenterol 2009;2:357-366.

17 Cameron DJ: Upper and lower gastrointestinal endoscopy in children and adolescents with Crohn's disease: a prospective study. J Gastroenterol Hepatol 1991;6:355-358.

$\checkmark 18$ Wagtmans MJ, Verspaget HW, Lamers CB, van Hogezand RA: Clinical aspects of Crohn's disease of the upper gastrointestinal tract: a comparison with distal Crohn's disease. Am J Gastroenterol 1997;92:1467-1471.

19 Isaacs KL: Upper gastrointestinal tract endoscopy in inflammatory bowel disease. Gastrointest Endosc Clin N Am 2002;12:451-462, vii.

20 Castellaneta SP, Afzal NA, Greenberg M, Deere H, Davies S, Murch SH, Walker-Smith JA, Thomson M, Srivistrava A: Diagnostic role of upper gastrointestinal endoscopy in pediatric inflammatory bowel disease. J Pediatr Gastroenterol Nutr 2004;39:257-261.

-21 Bourreille A, Ignjatovic A, Aabakken L, Loftus EV Jr, Eliakim R, Pennazio M, Bouhnik Y, Seidman E, Keuchel M, Albert JG, Ardizzone S, Bar-Meir S, Bisschops R, Despott EJ, Fortun PF, Heuschkel R, Kammermeier J, Leighton JA, Mantzaris GJ, Moussata D, Lo S, Paulsen V, Panés J, Radford-Smith G, Reinisch W, Rondonotti E, Sanders DS, Swoger JM, Yamamoto H, Travis S, Colombel JF, Van Gossum A: Role of small-bowel endoscopy in the management of patients with inflammatory bowel disease: an international OMED-ECCO consensus. Endoscopy 2009;41:618-637.

-22 Annunziata ML, Caviglia R, Papparella LG, Cicala M: Upper gastrointestinal involvement of Crohn's disease: a prospective study on the role of upper endoscopy in the diagnostic work-up. Dig Dis Sci 2012;57:1618-1623.

23 Fireman Z, Mahajna E, Broide E, Shapiro M, Fich L, Sternberg A, Kopelman Y, Scapa E: Diagnosing small bowel Crohn's disease with wireless capsule endoscopy. Gut 2003;52: 390-392.

24 Herrerías JM, Caunedo A, Rodríguez-Téllez M, Pellicer F, Herrerías JM Jr: Capsule endoscopy in patients with suspected Crohn's disease and negative endoscopy. Endoscopy 2003;35:564-568.

25 Schulmann K, Hollerbach S, Schmiegel W: Diagnosing small bowel Crohn's disease with wireless capsule endoscopy. Gut 2003;52: 1531-1532; author reply 1532.

26 Eliakim R, Adler SN: Capsule video endoscopy in Crohn's disease - the European experience. Gastrointest Endosc Clin N Am 2004; 14:129-137.

27 Jungles SL: Video wireless capsule endoscopy: a diagnostic tool for early Crohn's disease. Gastroenterol Nurs 2004;27:170-175.

28 Albert JG, Martiny F, Krummenerl A, Stock K, Lesske J, Göbel CM, Lotterer E, Nietsch $\mathrm{HH}$, Behrmann C, Fleig WE: Diagnosis of small bowel Crohn's disease: a prospective comparison of capsule endoscopy with magnetic resonance imaging and fluoroscopic enteroclysis. Gut 2005;54:1721-1727.

29 Chong AK, Taylor A, Miller A, Hennessy O, Connell W, Desmond P: Capsule endoscopy versus push enteroscopy and enteroclysis in suspected small-bowel Crohn's disease. Gastrointest Endosc 2005;61:255-261.

30 Marmo R, Rotondano G, Piscopo R, Bianco MA, Siani A, Catalano O, Cipolletta L: Capsule endoscopy versus enteroclysis in the detection of small-bowel involvement in Crohn's disease: a prospective trial. Clin Gastroenterol Hepatol 2005;3:772-776.

31 Swain P: Wireless capsule endoscopy and Crohn's disease. Gut 2005;54:323-326.

- 32 Voderholzer WA, Beinhoelzl J, Rogalla P, Murrer S, Schachschal G, Lochs H, Ortner MA: Small bowel involvement in Crohn's disease: a prospective comparison of wireless capsule endoscopy and computed tomography enteroclysis. Gut 2005;54:369-373.

33 Leighton JA, Triester SL, Sharma VK: Capsule endoscopy: a meta-analysis for use with obscure gastrointestinal bleeding and Crohn's disease. Gastrointest Endosc Clin N Am 2006; 16:229-250.

34 Levesque BG: Yield to diagnostic accuracy: capsule endoscopy in Crohn's disease. Gastrointest Endosc 2010;71:128-130.

35 Doherty GA, Moss AC, Cheifetz AS: Capsule endoscopy for small-bowel evaluation in Crohn's disease. Gastrointest Endosc 2011; 74:167-175.

36 Andre C, Descos L, Landais P, Fermanian J: Laboratory supplementation of Crohn's Disease Activity Index. Lancet 1980;2:594-595.

37 Andre C, Descos L, Landais P, Fermanian J: Assessment of appropriate laboratory measurements to supplement the Crohn's Disease Activity Index. Gut 1981;22:571-574.

-38 Brignola C, Campieri M, Bazzocchi G, Farruggia $P$, Tragnone A, Lanfranchi GA: A laboratory index for predicting relapse in asymptomatic patients with Crohn's disease. Gastroenterology 1986;91:1490-1494.

39 Hyams JS, Mandel F, Ferry GD, Gryboski JD, Kibort PM, Kirschner BS, Griffiths AM, Katz AJ, Boyle JT: Relationship of common laboratory parameters to the activity of Crohn's disease in children. J Pediatr Gastroenterol Nutr 1992;14:216-222.

40 Tromm A, Tromm CD, Hüppe D, Schwegler U, Krieg M, May B: Evaluation of different laboratory tests and activity indices reflecting the inflammatory activity of Crohn's disease. Scand J Gastroenterol 1992;27:774-778.

-41 Moran A, Jones A, Asquith P: Laboratory markers of colonoscopic activity in ulcerative colitis and Crohn's colitis. Scand J Gastroenterol 1995;30:356-360.

42 Sipponen T, Savilahti E, Kärkkäinen P, Kolho KL, Nuutinen H, Turunen U, Färkkilä M: Fecal calprotectin, lactoferrin, and endoscopic disease activity in monitoring anti-TNF- $\alpha$ therapy for Crohn's disease. Inflamm Bowel Dis 2008;14:1392-1398.

43 Schoepfer AM, Beglinger C, Straumann A, Trummler M, Vavricka SR, Bruegger LE, Seibold F: Fecal calprotectin correlates more closely with the Simple Endoscopic Score for Crohn's Disease (SES-CD) than CRP, blood leukocytes, and the CDAI. Am J Gastroenterol 2010;105:162-169.

44 Sipponen T, Björkesten CG, Färkkilä M, Nuutinen H, Savilahti E, Kolho KL: Faecal calprotectin and lactoferrin are reliable surrogate markers of endoscopic response during Crohn's disease treatment. Scand J Gastroenterol 2010;45:325-331.

45 Zubcevic N, Mesihovic R, Zubcevic S: Usefulness of laboratory data in estimation of Crohn's disease activity. Med Arh 2010;64:33-36.

46 Laharie D, Mesli S, El Hajbi F, Chabrun E, Chanteloup E, Capdepont M, Razaire S, de Lédinghen V, Zerbib F: Prediction of Crohn's disease relapse with faecal calprotectin in infliximab responders: a prospective study. Aliment Pharmacol Ther 2011;34:462-469.

47 Fagan EA, Dyck RF, Maton PN, Hodgson HJ, Chadwick VS, Petrie A, Pepys MB: Serum levels of C-reactive protein in Crohn's disease and ulcerative colitis. Eur J Clin Invest 1982; 12:351-359.

48 Boirivant M, Leoni M, Tariciotti D, Fais S, Squarcia O, Pallone F: The clinical significance of serum C-reactive protein levels in Crohn's disease. Results of a prospective longitudinal study. J Clin Gastroenterol 1988;10:401-405.

49 Chamouard P, Richert Z, Meyer N, Rahmi G, Baumann R: Diagnostic value of C-reactive protein for predicting activity level of Crohn's disease. Clin Gastroenterol Hepatol 2006;4: 882-887.

50 Franchimont D: C-reactive protein: informative or misleading marker of Crohn's disease? Inflamm Bowel Dis 2007;13:501-502.

-51 Tilakaratne S, Lemberg DA, Leach ST, Day AS: C-reactive protein and disease activity in children with Crohn's disease. Dig Dis Sci 2010;55:131-136.

52 Florin TH, Paterson EW, Fowler EV, Radford-Smith GL: Clinically active Crohn's disease in the presence of a low C-reactive protein. Scand J Gastroenterol 2006;41:306-311.

-53 Sipponen T, Savilahti E, Kolho KL, Nuutinen H, Turunen U, Färkkilä M: Crohn's disease activity assessed by fecal calprotectin and lactoferrin: correlation with Crohn's Disease Activity Index and endoscopic findings. Inflamm Bowel Dis 2008;14:40-46. 
54 Maconi G, Parente F, Bollani S, Cesana B, Bianchi Porro G: Abdominal ultrasound in the assessment of extent and activity of Crohn's disease: clinical significance and implication of bowel wall thickening. Am J Gastroenterol 1996;91:1604-1609.

-55 Haber HP, Busch A, Ziebach R, Stern M: Bowel wall thickness measured by ultrasound as a marker of Crohn's disease activity in children. Lancet 2000;355:1239-1240.

-56 Castiglione F, de Sio I, Cozzolino A, Rispo A, Manguso F, Del Vecchio Blanco G, Di Girolamo E, Castellano L, Ciacci C, Mazzacca G: Bowel wall thickness at abdominal ultrasound and the one-year-risk of surgery in patients with Crohn's disease. Am J Gastroenterol 2004;99:1977-1983.

-57 Parente F, Greco S, Molteni M, Anderloni A, Maconi G, Bianchi Porro G: Modern imaging of Crohn's disease using bowel ultrasound. Inflamm Bowel Dis 2004;10:452-461.

-58 Sturm EJ, Cobben LP, Meijssen MA, van der Werf SD, Puylaert JB: Detection of ileocecal Crohn's disease using ultrasound as the primary imaging modality. Eur Radiol 2004;14: 778-782.

59 Girlich C, Schacherer D, Jung EM, Schreyer A, Büttner R: Comparison between a clinical activity index (Harvey-Bradshaw Index), laboratory inflammation markers and quantitative assessment of bowel wall vascularization by contrast-enhanced ultrasound in Crohn's disease. Eur J Radiol 2012;81:1105-1109.

-60 Kerber GW, Greenberg M, Rubin JM: Computed tomography evaluation of local and extraintestinal complications of Crohn's disease. Gastrointest Radiol 1984;9:143-148.

61 Gore RM, Cohen MI, Vogelzang RL, Neiman HL, Tsang TK: Value of computed tomography in the detection of complications of Crohn's disease. Dig Dis Sci 1985;30:701-709.

62 Colombel JF, Solem CA, Sandborn WJ, Booya F, Loftus EV Jr, Harmsen WS, Zinsmeister AR, Bodily KD, Fletcher JG: Quantitative measurement and visual assessment of ileal Crohn's disease activity by computed tomography enterography: correlation with endoscopic severity and C-reactive protein. Gut 2006;55:1561-1567.

-63 Schreyer AG, Geissler A, Albrich H, Schölmerich J, Feuerbach S, Rogler G, Völk M, Herfarth $\mathrm{H}$ : Abdominal MRI after enteroclysis or with oral contrast in patients with suspected or proven Crohn's disease. Clin Gastroenterol Hepatol 2004;2:491-497.

-64 Schreyer AG, Gölder S, Scheibl K, Völk M, Lenhart M, Timmer A, Schölmerich J, Feuerbach S, Rogler G, Herfarth H, Seitz J: Dark lumen magnetic resonance enteroclysis in combination with MRI colonography for whole bowel assessment in patients with Crohn's disease: first clinical experience. Inflamm Bowel Dis 2005;11:388-394.

65 Gourtsoyiannis NC, Grammatikakis J, Papamastorakis G, Koutroumbakis J, Prassopoulos $\mathrm{P}$, Rousomoustakaki M, Papanikolaou $\mathrm{N}$ : Imaging of small intestinal Crohn's dis- ease: comparison between MR enteroclysis and conventional enteroclysis. Eur Radiol 2006;16:1915-1925.

66 Malagò R, Manfredi R, Benini L, D’Alpaos G, Mucelli RP: Assessment of Crohn's disease activity in the small bowel with MR-enteroclysis: clinico-radiological correlations. Abdom Imaging 2008;33:669-675.

67 Koilakou S, Sailer J, Peloschek P, Ferlitsch A, Vogelsang $\mathrm{H}$, Miehsler $\mathrm{W}$, Fletcher J, Turetschek K, Schima W, Reinisch W: Endoscopy and MR enteroclysis: equivalent tools in predicting clinical recurrence in patients with Crohn's disease after ileocolic resection. Inflamm Bowel Dis 2010;16:198-203.

68 Schreyer AG, Hoffstetter P, Daneschnejad M, Jung EM, Pawlik M, Friedrich C, Fellner C, Strauch U, Klebl F, Herfarth H, Zorger N: Comparison of conventional abdominal CT with MR enterography in patients with active Crohn's disease and acute abdominal pain. Acad Radiol 2010;17:352-357.

69 Herfarth H, Palmer L: Risk of radiation and choice of imaging. Dig Dis 2009;27:278-284.

70 Palmer L, Herfarth H, Porter CQ, Fordham LA, Sandler RS, Kappelman MD: Diagnostic ionizing radiation exposure in a populationbased sample of children with inflammatory bowel diseases. Am J Gastroenterol 2009;104: 2816-2823.

71 Papay P, Ignjatovic A, Karmiris K, Amarante H, Milheller P, Feagan B, D'Haens G, Marteau P, Reinisch W, Sturm A, Steinwurz F, Egan L, Panés J, Louis E, Colombel JF, Panaccione R: Optimising monitoring in the management of Crohn's disease: a physician's perspective. J Crohns Colitis 2013;7:653-669.

72 Brenner DJ, Hall EJ: Computed tomography - an increasing source of radiation exposure. N Engl J Med 2007;357:2277-2284.

73 Berrington de González A, Darby S: Risk of cancer from diagnostic X-rays: estimates for the UK and 14 other countries. Lancet 2004; 363:345-351.

74 Doll R, Peto R: The causes of cancer: quantitative estimates of avoidable risks of cancer in the United States today. J Natl Cancer Inst 1981;66:1191-1308.

75 Peloquin JM, Pardi DS, Sandborn WJ, Fletcher JG, McCollough CH, Schueler BA, Kofler JA, Enders FT, Achenbach SJ, Loftus EV Jr: Diagnostic ionizing radiation exposure in a population-based cohort of patients with inflammatory bowel disease. Am J Gastroenterol 2008;103:2015-2022.

76 Masselli G, Casciani E, Polettini E, Gualdi G: Comparison of MR enteroclysis with MR enterography and conventional enteroclysis in patients with Crohn's disease. Eur Radiol 2008; 18:438-447.

77 Makó EK, Mester AR, Tarján Z, Karlinger K, Tóth G: Enteroclysis and spiral CT examination in diagnosis and evaluation of small bowel Crohn's disease. Eur J Radiol 2000;35:168175.

78 Sailer J, Peloschek P, Schober E, Schima W, Reinisch W, Vogelsang H, Wunderbaldinger
P, Turetschek K: Diagnostic value of CT enteroclysis compared with conventional enteroclysis in patients with Crohn's disease. AJR Am J Roentgenol 2005; 185:1575-1581.

79 Kohli MD, Maglinte DD: CT enteroclysis in small bowel Crohn's disease. Eur J Radiol 2009;69:398-403.

80 Gatta G, Di Grezia G, Di Mizio V, Landolfi C, Mansi L, De Sio I, Rotondo A, Grassi R: Crohn's disease imaging: a review. Gastroenterol Res Pract 2012, DOI: 10.1155/2012/ 816920. Epub 2012 Jan 18.

81 Herfarth HH, Grunert M, Klebl F, Strauch U, Feuerbach S, Schölmerich J, Rogler G, Schreyer AG: Frequency and nature of incidental extra-enteric lesions found on magnetic resonance enterography (MR-E) in patients with inflammatory bowel diseases (IBD). PLoS One 2009;4:e4863.

82 Rafal RB, Nichols JN, Cennerazzo WJ, Kazam E, DeCosse JJ: MRI for evaluation of perianal inflammation. Abdom Imaging 1995;20:248252.

83 Borley NR, Mortensen NJ, Jewell DP: MRI scanning in perianal Crohn's disease: an important diagnostic adjunct. Inflamm Bowel Dis 1999;5:231-233; discussion 234.

84 Szurowska E, Wypych J, Izycka-Swieszewska E: Perianal fistulas in Crohn's disease: MRI diagnosis and surgical planning: MRI in fistulazing perianal Crohn's disease. Abdom Imaging 2007;32:705-718.

85 Wise PE, Schwartz DA: The evaluation and treatment of Crohn perianal fistulae: EUA, EUS, MRI, and other imaging modalities. Gastroenterol Clin North Am 2012;41:379-391.

-86 Schwartz DA, Wiersema MJ, Dudiak KM, Fletcher JG, Clain JE, Tremaine WJ, Zinsmeister AR, Norton ID, Boardman LA, Devine RM, Wolff BG, Young-Fadok TM, Diehl NN, Pemberton JH, Sandborn WJ: A comparison of endoscopic ultrasound, magnetic resonance imaging, and exam under anesthesia for evaluation of Crohn's perianal fistulas. Gastroenterology 2001;121:1064-1072.

-87 Schwartz DA, White CM, Wise PE, Herline AJ: Use of endoscopic ultrasound to guide combination medical and surgical therapy for patients with Crohn's perianal fistulas. Inflamm Bowel Dis 2005;11:727-732.

88 Maconi G, Ardizzone S, Greco S, Radice E, Bezzio C, Bianchi Porro G: Transperineal ultrasound in the detection of perianal and rectovaginal fistulae in Crohn's disease. Am J Gastroenterol 2007;102:2214-2219.

$\$ 89$ Losco A, Viganò C, Conte D, Cesana BM, Basilisco G: Assessing the activity of perianal Crohn's disease: comparison of clinical indices and computer-assisted anal ultrasound. Inflamm Bowel Dis 2009;15:742-749.

90 Rosen MJ, Moulton DE, Koyama T, Morgan WM 3rd, Morrow SE, Herline AJ, Muldoon RL, Wise PE, Polk DB, Schwartz DA: Endoscopic ultrasound to guide the combined medical and surgical management of pediatric perianal Crohn's disease. Inflamm Bowel Dis 2010;16:461-468.
Monitoring Disease Activity and Progression in Crohn's Disease
Digestion 2014;89:299-309 DOI: $10.1159 / 000360283$ 
91 Lahat A, Assulin Y, Beer-Gabel M, Chowers Y: Endoscopic ultrasound for perianal Crohn's disease: disease and fistula characteristics, and impact on therapy. J Crohns Colitis 2012;6:311-316.

92 Siddiqui MR, Ashrafian H, Tozer P, Daulatzai N, Burling D, Hart A, Athanasiou T, Phillips RK: A diagnostic accuracy meta-analysis of endoanal ultrasound and MRI for perianal fistula assessment. Dis Colon Rectum 2012;55:576-585.

93 Pallotta N, Baccini F, Corazziari E: Small intestine contrast ultrasonography (SICUS) in the diagnosis of small intestine lesions. Ultrasound Med Biol 2001;27:335-341.

\$4 Ripollés T, Martínez-Pérez MJ, Blanc E, Delgado F, Vizuete J, Paredes JM, Vilar J: Contrast-enhanced ultrasound (CEUS) in Crohn's disease: technique, image interpretation and clinical applications. Insights Imaging 2011;2:639-652.

$\$ 95$ De Franco A, Marzo M, Felice C, Pugliese D, Veronica AD, Bonomo L, Armuzzi A, Guidi L: Ileal Crohn's disease: CEUS determination of activity. Abdom Imaging 2012;37: 359-368.

$\$ 6$ Pallotta N, Vincoli G, Montesani C, Chirletti P, Pronio A, Caronna R, Ciccantelli B, Romeo E, Marcheggiano A, Corazziari E: Small intestine contrast ultrasonography (SICUS) for the detection of small bowel complications in Crohn's disease: a prospective comparative study versus intraoperative findings. Inflamm Bowel Dis 2012;18:74-84.

$\$ 97$ Kallel L, Ayadi I, Matri S, Fekih M, Mahmoud NB, Feki M, Karoui S, Zouari B, Boubaker J, Kaabachi N, Filali A: Fecal calprotectin is a predictive marker of relapse in Crohn's disease involving the colon: a prospective study. Eur J Gastroenterol Hepatol 2010;22:340-345.

$\$ 98$ De Bona M, Bellumat A, Cian E, Valiante F, Moschini A, De Boni M: Capsule endoscopy findings in patients with suspected Crohn's disease and biochemical markers of inflammation. Dig Liver Dis 2006;38:331-335.

99 Erber WF, Erber JA: Meta-analysis of the yield of capsule endoscopy in patients with Crohn's disease. Am J Gastroenterol 2006; 101:2669.

100 Eliakim R: The impact of capsule endoscopy on Crohn's disease. Dig Liver Dis 2007;39: 154-155.

-101 Figueiredo P, Almeida N, Lopes S, Duque G, Freire P, Lérias C, Gouveia H, Sofia C: Smallbowel capsule endoscopy in patients with suspected Crohn's disease - diagnostic value and complications. Diagn Ther Endosc 2010;2010:101284.

-102 Kiss LS, Papp M, Lovasz BD, Vegh Z, Golovics PA, Janka E, Varga E, Szathmari M, Lakatos PL: High-sensitivity C-reactive protein for identification of disease phenotype, active disease, and clinical relapses in Crohn's disease: a marker for patient classification? Inflamm Bowel Dis 2012;18: 1647-1654.
103 Prantera C, Luzi C, Olivotto P, Levenstein S, Cerro P, Fanucci A: Relationship between clinical and laboratory parameters and length of lesion in Crohn's disease of small bowel. Dig Dis Sci 1984;29:1093-1097.

104 Wright JM, Adams SP, Gribble MJ, Bowie WR: Clostridium difficile in Crohn's disease. Can J Surg 1984;27:435-437.

105 Kurtz LE, Yang SS, Bank S: Clostridium difficile-associated small bowel enteritis after total proctocolectomy in a Crohn's disease patient. J Clin Gastroenterol 2010;44:76-77.

106 Adani GL, Avital I, Ferraresso C, Aoki T: CMV infection in severe refractory ulcerative and Crohn's colitis. Am J Gastroenterol 2001;96:3464-3465.

107 Shahani L: CMV infection complicating the diagnosis of Crohn's disease in an immunocompetent patient. BMJ Case Rep 2012, DOI: 10.1136/bcr.11.2011.5254.

108 Sempere GA, Martinez Sanjuan V, Medina Chulia E, Benages A, Tome Toyosato A, Canelles P, Bulto A, Quiles F, Puchades I, Cuquerella J, Celma J, Orti E: MRI evaluation of inflammatory activity in Crohn's disease. AJR Am J Roentgenol 2005;184:18291835.

109 Martínez MJ, Ripollés T, Paredes JM, Blanc E, Martí-Bonmatí L: Assessment of the extension and the inflammatory activity in Crohn's disease: comparison of ultrasound and MRI. Abdom Imaging 2009;34:141-148.

110 Maccioni F, Viola F, Carrozzo F, Di Nardo G, Pino AR, Staltari I, Al Ansari N, Vestri A, Signore A, Marini M, Cucchiara S: Differences in the location and activity of intestinal Crohn's disease lesions between adult and paediatric patients detected with MRI. Eur Radiol 2012;22:2465-2477.

-111 Biancone L, Calabrese E, Petruzziello C, Onali S, Caruso A, Palmieri G, Sica GS, Pallone F: Wireless capsule endoscopy and small intestine contrast ultrasonography in recurrence of Crohn's disease. Inflamm Bowel Dis 2007;13:1256-1265.

112 Brenner DJ: Should computed tomography be the modality of choice for imaging Crohn's disease in children? The radiation risk perspective. Gut 2008;57:1489-1490.

113 Siddiki H, Fletcher JG, Hara AK, Kofler JM, McCollough CH, Fidler JL, Guimaraes L, Huprich JE, Sandborn WJ, Loftus EV Jr, Mandrekar J, Bruining DH: Validation of a lower radiation computed tomography enterography imaging protocol to detect Crohn's disease in the small bowel. Inflamm Bowel Dis 2011;17:778-786.

114 Mendoza JL: Ionizing radiation in Crohn's disease. Rev Esp Enferm Dig 2012;104:449451.

115 Maconi G, Sampietro GM, Parente F, Pompili G, Russo A, Cristaldi M, Arborio G, Ardizzone S, Matacena G, Taschieri AM, Bianchi Porro G: Contrast radiology, computed tomography and ultrasonography in detecting internal fistulas and intra-abdominal abscesses in Crohn's disease: a prospective comparative study. Am J Gastroenterol 2003;98:1545-1555.

116 Paparo F, Bacigalupo L, Garello I, Biscaldi E, Cimmino MA, Marinaro E, Rollandi GA Crohn's disease: prevalence of intestinal and extraintestinal manifestations detected by computed tomography enterography with water enema. Abdom Imaging 2012;37:326337.

117 Tarján Z, Tóth G, Györke T, Mester A, Karlinger K, Makó EK: Ultrasound in Crohn's disease of the small bowel. Eur J Radiol 2000; 35:176-182.

118 Rigazio C, Ercole E, Laudi C, Daperno M, Lavagna A, Crocella L, Bertolino F, Viganò L, Sostegni R, Pera A, Rocca R: Abdominal bowel ultrasound can predict the risk of surgery in Crohn's disease: proposal of an ultrasonographic score. Scand J Gastroenterol 2009;44:585-593.

119 Rutgeerts P, Diamond RH, Bala M, Olson A, Lichtenstein GR, Bao W, Patel K, Wolf DC, Safdi M, Colombel JF, Lashner B, Hanauer SB: Scheduled maintenance treatment with infliximab is superior to episodic treatment for the healing of mucosal ulceration associated with Crohn's disease. Gastrointest Endosc 2006;63:433-442; quiz 464.

120 Schnitzler F, Fidder H, Ferrante M, Noman M, Arijs I, Van Assche G, Hoffman I, Van Steen K, Vermeire S, Rutgeerts P: Mucosal healing predicts long-term outcome of maintenance therapy with infliximab in Crohn's disease. Inflamm Bowel Dis 2009; 15:1295-1301.

121 Baert F, Moortgat L, Van Assche G, Caenepeel P, Vergauwe P, De Vos M, Stokkers P, Hommes D, Rutgeerts P, Vermeire S, D'Haens G: Mucosal healing predicts sustained clinical remission in patients with early-stage Crohn's disease. Gastroenterology 2010;138:463-468; quiz e410-e461.

122 Flynn A, Kane S: Mucosal healing in Crohn's disease and ulcerative colitis: what does it tell us? Curr Opin Gastroenterol 2011;27:342345.

123 Danese S, Peyrin-Biroulet L: IBD: mucosal healing - EXTENDing our knowledge in Crohn's disease. Nat Rev Gastroenterol Hepatol 2012;9:309-311.

124 De Cruz P, Kamm MA, Prideaux L, Allen PB, Moore G: Mucosal healing in Crohn's disease: a systematic review. Inflamm Bowel Dis 2013;19:429-444.

125 Peyrin-Biroulet L, Danese S: Stopping infliximab in Crohn's disease: still an ongoing STORI. Inflamm Bowel Dis 2012;18:22012202.

126 Rutgeerts P: Strategies in the prevention of post-operative recurrence in Crohn's disease. Best Pract Res Clin Gastroenterol 2003; 17:63-73.

127 Pascua M, Su C, Lewis JD, Brensinger C, Lichtenstein GR: Meta-analysis: factors predicting post-operative recurrence with placebo therapy in patients with Crohn's disease. Aliment Pharmacol Ther 2008;28:545-556. 
128 Doherty G, Bennett G, Patil S, Cheifetz A, Moss AC: Interventions for prevention of post-operative recurrence of Crohn's disease. Cochrane Database Syst Rev 2009;4:CD006873, DOI: 10.1002/14651858. CD006873.pub2. Review.

129 D'Haens GR, Rutgeerts PL: Postoperative recurrence of Crohn's disease: pathogenesis and prevention. Acta Gastroenterol Belg 1994;57:311-313.

130 Rutgeerts P: Clinical risk factors determining recurrence in Crohn's disease. Gastroenterol Hepatol 1996;19:44-46.

131 D’Haens G, Rutgeerts P: Postoperative recurrence of Crohn's disease: pathophysiology and prevention. Inflamm Bowel Dis 1999;5:295-303.
132 Van Assche G, Rutgeerts P: Medical management of postoperative recurrence in Crohn's disease. Gastroenterol Clin North Am 2004;33:347-360.

133 Rutgeerts P: Recurrence of Crohn's disease after surgery - the need for treatment of new lesions. Aliment Pharmacol Ther 2006; 24(suppl 3):29-32.
134 Orlando A, Modesto I, Castiglione F, Scala L, Scimeca D, Rispo A, Teresi S, Mocciaro F, Criscuoli V, Marrone C, Platania P, De Falco T, Maisano S, Nicoli N, Cottone M: The role of calprotectin in predicting endoscopic postsurgical recurrence in asymptomatic Crohn's disease: a comparison with ultrasound. Eur Rev Med Pharmacol Sci 2006;10:17-22.

135 Lamb CA, Mohiuddin MK, Gicquel J, Neely D, Bergin FG, Hanson JM, Mansfield JC: Faecal calprotectin or lactoferrin can identify postoperative recurrence in Crohn's disease. Br J Surg 2009;96:663-674.

136 Seibold F, Schoepfer AM: Can fecal calprotectin or lactoferrin identify postoperative recurrence in Crohn's disease? Inflamm Bowel Dis 2010;16:1814-1815. 